\title{
CJEU VAT Case Law in 2020: Evergreens, Revivals and New Trends
}

\section{INTRODUCTION}

In 2020, the CJEU handed down approximately forty judgments and orders dealing with VAT issues. Compared to prior years, this is not a prominent number but is about average. ${ }^{1}$ Against the procedural background, the number of judgments and orders and the subject matters dealt therein cannot serve to identify clear trends as they are, to some extent, arbitrary. It must always be kept in mind that the CJEU cannot get active on its own motion but is dependent on actions taken by domestic courts (preliminary rulings) or the European Commission (infringement proceedings). Moreover, the Court is limited to the questions asked by the domestic courts and the pleas brought forward by the Commission and, as a general rule, will not go beyond that scope. ${ }^{2}$ Finally, the time of publication of a judgment or order also depends on procedural aspects (e.g., whether an opinion by an Advocate General is published) and may take approximately two years after the decision on a request for a preliminary ruling is made by the domestic court or an action is brought to the CJEU by the Commission. ${ }^{3}$ Hence, the CJEU judgment or order actually reflects a dispute that kept domestic authorities and courts busy already a number of years back. Thus, there is always a time lag involved. Despite these limitations, this paper will attempt to identify recent trends in the CJEU jurisprudence in the area of VAT and their potential future impact on legislation, case law, and VAT practice. Due to the amount of case law, this paper does not aim at comprehensively covering all judgments and orders handed down in 2020 but selects some of the most interesting ones. 4

The CJEU cases of last year that are discussed in this paper may be divided into three main categories:

- 'evergreen' issues that have been disputed for decades (FE concept, direct link for input VAT deduction, bad debt relief);

- revival of topics that have not been extensively discussed by the Court for some years (double taxation); and

- new areas of interest that have largely lacked jurisprudence so far (in particular the undisclosed agent rule in Article 28 VAT Directive and refund of input VAT).

Many of these cases interestingly also link to current, ongoing (reform) discussions at the EU level. Although this association seems to be coincidental, it nevertheless stresses the importance of the issues decided on by the CJEU.

\section{Evergreens}

\section{I Fixed Establishment (FE) Concept}

One of the most important cases of 2020 was the Dong Yang case dealing with the 'fixed establishment' (FE) concept. ${ }^{5}$ The FE concept has been heavily discussed in CJEU cases and in VAT practice ever since the early Berkholz case of $1985 .{ }^{6}$ Interpretation issues surround

\section{Notes}

2019: 45 judgment and orders; 2018: Forty-five judgment and orders; 2017: Forty-nine judgments and orders; 2016: Twenty-nine judgments and orders; 2015: Thirty-nine judgments and orders; Numbers based on the search function in curia.europa.eu, by using 'value-added tax' as 'subject-matter'.

2 See inter alia, CJEU 20 Mar. 1997, Phytheron, Case C-352/95, ECLI:EU:C:1997:170, para. 14; in more detail, C. Latzel \& T. Streinz, Das richtige Vorabentscheidungsersuchen, 13 (4) Neue Juristische Online-Zeitschrift 97, 104 (2013).

See e.g., the Dong Yang case (CJEU 7 May 2020, Dong Yang, Case C-547/18, ECLI:EU:C:2020:350): decision by the domestic court on the request for a preliminary ruling made on 6 June 2018; CJEU judgment published on 7 May 2020.

4 See on other interesting VAT cases of 2020, inter alia, S. Cazes, Positive Outcome for Businesses of Recent VAT Cases from the Court of Justice of the European Union, 48(10) Intertax 934 (2020).

Dong Yang (C-547/18), supra n. 3.

6 CJEU 4 July 1985, Berkholz, Case C-168/84, ECLI:EU:C:1985:299. 
the definition of an FE (human and technical resources, permanence), ${ }^{7}$ its 'VAT personality', ${ }^{8}$ whether a subsidiary can qualify as one, ${ }^{9}$ and the allocation of supplies to an FE. ${ }^{10}$ Although the FE concept has been defined and regulated to some extent with an amendment to the Implementing Regulation 282/2011/EU (see Articles 11, 22 , and 53$)^{11}$ having effect from 1 July 2011, this has not established legal certainty for all issues. ${ }^{12}$

The Dong Yang case (referral from Poland) concerns the allocation of taxing rights on a B2B supply of services based on the place of supply rule in Article 44 VAT Directive in a scenario involving a non-EU Member State. It is the first CJEU judgment relating to facts falling within the temporal scope of the new rules in the Implementing Regulation, ${ }^{13}$ the second CJEU judgment concerning a receiving $\mathrm{FE}$ as place of supply within the scope of Article 44 EU VAT Directive ${ }^{14}$ and the fourth CJEU judgment on the question of whether a subsidiary can qualify as an FE of its parent for VAT purposes. ${ }^{15}$

The primary questions in Dong Yang were whether an EU subsidiary of a non-resident (third country) parent may create an FE for the parent for purposes of Article 44 VAT Directive and how the supplier of the services can verify whether this is the case. By referring to its famous DFDS case of $1997,{ }^{16}$ the CJEU did not - similar to previous cases ${ }^{17}$ - provide a final answer on whether the subsidiary should be 'downgraded' to an FE in the specific case; the Court merely held, in rather general terms, that this requires the assessment of the conditions in 'Article
11 [Implementing Regulation] ... in the light of economic and commercial realities'. ${ }^{18}$ When performing this assessment, the supplier is, according to the Court, however, not obligated to verify the contractual relationship between the parent and subsidiary on the customer side (as this information is beyond his control). ${ }^{19}$ To sum up: the (disputed) DFDS doctrine 'is still alive', ${ }^{20}$ although its scope of application within Article 44 appears to be limited.

In March 2021, the Dong Yang case was followed by an equally important judgment on the FE concept: Danske Bank - a referral by a Swedish court on a modified Skandia situation. ${ }^{21}$ Following the Skandia case, ${ }^{22}$ the CJEU ruled that cross-border head office-branch transactions (internal recharges of costs) are subject to VAT if the head office or fixed establishment belongs to a domestic VAT group. In other words: VAT grouping prevails over the FCE Bank doctrine ${ }^{23}$ and may break the bond between the head office and the fixed establishment. Overall, when summarizing and reconciling Dong Yang and Danske Bank, the information is ambiguous: depending on the individual case and the specific disputed provision to be interpreted, an FE may be considered as independent and a subsidiary as dependent for VAT purposes.

More cases on the FE concept are currently pending: there is the Titanium case from Austria (on the need for personnel resources to establish an FE) ${ }^{24}$ and the Berlin Chemie case from Germany (on the question of whether

\section{Notes}

Ibid: CJEU 17 July 1997, Aro Lease, Case C-190/95, ECLI:EU:C:1997:374; CJEU 7 May 1998, Lease Plan, Case C-390/96, ECLI:EU:C:1998:206.

8 CJEU 23 Mar. 2006, FCE Bank, Case C-210/04, ECLI:EU:C:2006:196; CJEU 17 Sept. 2014, Skandia, Case C-7/13, ECLI:EU:C:2014:2225; CJEU 7 Aug. 2018, TGE, Case C-16/17, ECLI:EU:C:2018:647; compare on this issue M. Merkx, Fixed Establishments in European VAT, 127 (Wolters Kluwer 2013); R. Mikutiene, The Preferred Treatment of the Fixed Establishment in European VAT, 3(3) World J. VAT/GST L. 166, 167 et seq. (2014); C. Herbain, The Journey of Branches Into VAT Schizopbrenia, 2(3) World J. VAT/ GST L. 203, 204 (2013)

9 CJEU 20 Feb. 1997, DFDS, Case C-260/95, ECLI:EU:C:1997:77; CJEU 16 Oct. 2014, Welmory, Case C-605/12, ECLI:EU:C:2014:2298.

10 Welmory (C-605/12), supra n. 9.

11 Council Implementing Regulation 282/2011/EU of 15 Mar. 2011 laying down implementing measures for Directive 2006/112/EC on the common system of value added tax, OJ L 77/1 (23 Mar. 2011).

12 See inter alia, M. Merkx, Fixed Establishments in EU VAT - Between Delusion and Reality, 23(1) Int'l VAT Monitor 22, 22 (2012); Mikutiene, supra n. 8; K. Spies, Permanent Establishments in Value Added Tax, WU Series Vol. 13, 177 et seq. (IBFD 2020).

13 In Welmory (C-605/12), supra n. 9, the CJEU addressed the rules in the IR even though the regulation was not yet in force at the material time of the case (see paras 46 et seq.).

14 First case: Welmory (C-605/12), supra n. 9. However, Dong Yang (C-547/18), supra n. 3, is the first case in relation to a non-EU-Member State.

15 First case: DFDS (C-260/95), supra n. 9; second case: CJEU 25 Oct. 2012, Daimler and Widex, Joined Cases C-318/11 and C-319/11, ECLI:EU:C:2012:666; third case: Welmory (C-605/12), supra n. 9

16 Dong Yang (C-547/18), supra n. 3, para. 32.

17 See Welmory (C-605/12), supra n. 9.

18 Dong Yang (C-547/18), supra n. 3, para. 32.

19 Ibid., paras 34-47.

20 See G. Beretta, Dong Yang Electronics (Case C-547/18): Ob Yes, a Subsidiary Can (also) Be a Fixed Establishment Under EU VAT, but Information Asymmetries May Save You', Kluwer International Tax Blog (15 June 2020), http://kluwertaxblog.com/2020/06/15/dong-yang-electronics-case-c-547-18-oh-yes-a-subsidiary-can-also-be-a-fixed-estab lishment-under-eu-vat-but-information-asymmetries-may-save-you/ (accessed 9 Feb. 2021)

21 CJEU 11 Mar. 2021, C-812/19, Danske Bank A/S, ECLI:EU:C:2021:196

22 Skandia (C-7/13), supra n. 8 .

3 FCE Bank (C-210/04), supra n. 8.

24 Request for a preliminary ruling from the Bundesfinanzgericht (Austria) lodged on 20 Dec. 2019, Titanium, Case C-931/19, OJ C 87/10 (16 Mar. 2020); see on this case also M. van de Leur, New Developments in the 'Fixed Establishment' Concept for VAT Purposes, 31(3) Int'l VAT Monitor 115 (2020). 
[outsourced] third-party resources can lead to an FE). ${ }^{25}$ Even though these referrals prove that the FE concept would need 'fixing, ${ }^{26}$ the disagreement in the VAT Committee in 2019 on whether to consider a call-off stock warehouse to be a fixed establishment of the supplier $^{27}$ made clear that Member States will not agree on any further harmonization in the medium (possibly even long) term. This 'evergreen' will hence certainly continue to lead to controversial discussions at the Court level, in academia, and in practice.

\section{2 'Direct Link' as Requirement for Input VAT Credit}

Another evergreen is the condition of a 'direct link' for input VAT deduction. According to settled case law, a taxable person is entitled to deduct input VAT if there is a 'direct and immediate link' between a particular input transaction and a particular output transaction creating an entitlement to deduct (i.e., taxed transaction) ${ }^{28}$ or the 'economic activity as a whole'. ${ }^{29}$ Recent cases added a new element to the discussions, specifically, whether spill-over effects (i.e., benefits from the purchases for third parties or the general public) are detrimental to the direct link between input costs and taxed output transactions. ${ }^{30}$

This aspect has already been briefly discussed in the Becker, Iberdrola, and Sveda cases ${ }^{31}$ and was more comprehensively addressed by the Court in 2020 in the Mitteldeutsche Hartstein Industrie AG (on the building of public roads) and Vos Aannemingen cases (regarding marketing costs for the sale of partly third-party owned assets). The CJEU continues to apply a business-friendly approach by referring to the neutrality principle ${ }^{32}$ : Benefits for third parties or the general public are not detrimental to input VAT credit as long as the costs are 'essential' for the economic activity of the taxable person ${ }^{33}$ and as long as the benefits for third parties are merely 'ancillary'. ${ }^{34}$ Even if the asset (e.g., public road) is subsequently transferred to the state free of charge, this does not lead to VAT costs for businesses; the self-supply rules are not effectuated as long as the purchases are a factor in the cost of taxed output transactions and the consumption does hence not remain untaxed. ${ }^{35}$ The Court thereby dismissed the stricter practice by some Member States' (including Austria and Germany) authorities and courts. ${ }^{36}$

Also, this line of case law is not yet fully consistent and clear. Questions on the seemingly new conditions of 'essential' costs (e.g., does this involve a reasonableness test for business expenses?) and 'ancillary' benefits and their relationship (e.g., why is the benefit for the state/ public deriving from a public road still considered 'ancillary'?) and potential contradictions with earlier case law (e.g., why does a promotional gift to potential customers, as held in Kuwait Petroleum, ${ }^{37}$ trigger a self-supply whereas the free-of-charge transfer of a public road to a municipality does not?) will presumably initiate follow-up referrals by domestic courts in the near future.

\subsection{Taxable Amount and Consideration Adjustments}

Questions on the taxable amount and consideration adjustments in VAT has increasingly occupied the Court's time over the last couple of years. ${ }^{38}$ In 2020 , the CJEU passed down several preliminary rulings that might be classified as follow-up to clarify questions to previous judgments.

\section{Notes}

25 Request for a preliminary ruling from the Curtea de Apel Bucure冈ti (Romania) lodged on 22 July 2020, Berlin Chemie, Case C-333/20, OJ C 339/2 (12 Oct. 2020).

26 S. Cornielje \& P. Slegtenhorst, The Unsettled Business of the Fixed Establishment in EU VAT, 29(6) EC Tax Rev. 285, 294 (2020); see on the controversial case law in Poland: K. Lasinski-Sulecki, Fixed Establishment: From Berkbolz and DFDS to Welmory and Dong Yang, 31(4) Int'1 VAT Monitor 189 (2020).

27 European Commission, VAT Committee, Minutes of the 113th Meeting, s. 3.1, taxud.c.1(2019)6187445 (3 Sept. 2019).

28 CJEU 8 June 2000, Midland Bank, Case C-98/98, ECLI:EU:C:2000:300, para. 24

29 CJEU 29 Oct. 2009, SKF, Case C-29/08, ECLI:EU:C:2009:665, para. 58

30 See also J. Bijl, VAT Deduction: The Relevance of Being 'The Recipient' of a Supply and the Use of the Supply, 29(5) EC Tax Rev. 227 (2020).

31 CJEU 19 Jan. 1982, Becker, Case C-8/81, ECLI:EU:C:1982:7; CJEU 22 Oct. 2015, Sveda, Case C-126/14, ECLI:EU:C:2015:712; CJEU 14 Sept. 2017, Iberdrola, Case C-132/ 16, ECLI:EU:C:2017:683.

32 CJEU 16 Sept. 2020, Mitteldeutsche Hartstein Industrie AG, Case C-528/19, ECLI:EU:C:2020:712, para. 24; CJEU 1 Oct. 2020, Vos Aannemingen, Case C-405/19, ECLI:EU: C:2020:785, para. 29

3 Mitteldeutsche Hartstein Industrie AG (C-528/19), supra n. 32, paras 32 and 39

4 Vos Aannemingen (C-405/19), supra n. 32, paras 28 et seq

5 Mitteldeutsche Hartstein Industrie AG (C-528/19), supra n. 32, paras 66-67.

36 DE: Federal Fiscal Court (BFH), judgment of 13 Jan. 2011, Case V R 12/08; AT: Supreme Administrative Court (VwGH) judgment of 25 July 2013, Case 2011/15/0055; and AT: Supreme Administrative Court (VwGH) judgment of 19 Dec. 2013, Case 2009/15/0137.

37 CJEU 27 Apr. 1999, Kuwait Petroleum, Case C-48/97, ECLI:EU:C:1999:203, paras 29 et seq.

38 See on the case law, inter alia, A. van Doesum \& F. Nellen, Taxable Amount and VAT Rates, in CJEU - Recent Developments in Value Added Tax 2017 , V, 250,251 et seq. (G. Kofler et al. eds, Linde 2018). 
The Vodafone case handed down in $2020^{39}$ builds on the MEO case from $2018^{40}$ and the Air France KLM case of $2015 .{ }^{41}$ It deals with the question of whether a payment by the customer made upon early termination of a contract due to reasons attributable to the customer is a taxable consideration or a non-taxable compensation for damages. The Court applied a substance-over-form approach and detached the VAT classification of the agreed payments in the specific cases from the civil law classification. Considering 'economic reality', ${ }^{42}$ the payment is not a compensation for damages but 'seeks to guarantee the operator a minimum contractual remuneration for the service provided $^{, 43}$ and is thus subject to VAT. In MEO, this is supported with the argument that the payment by the customer in question was equivalent to the amount that the operator would have received as remuneration for the remainder of the contractual period. ${ }^{44}$ However, in Vodafone, the disputed amount did not correspond to the agreed remuneration; ${ }^{45}$ this did not prevent the Court from qualifying the payment as remuneration for a supply, specifically, for the 'right' to use the service. ${ }^{46}$ It is unclear how this new line of case law can be reconciled with the earlier Société thermale d'Eugénie-Les-Bains case of 2007 according to which forfeited deposits in the hotel sector classify as non-taxable damages. ${ }^{47}$

Another discussion point in recent case law related to the taxable amount in VAT are bad debt reliefs. In the $E$. and SCT cases in 2020, the Court - building on the famous Di Maura case of $2017^{48}$ - had to address questions on the VAT treatment of non-payment due to a debtor's insolvency. In both judgments, the CJEU stressed, with reference to the principles of proportionality and neutrality, that a taxable person must be granted the right to reduce the taxable amount if a claim becomes irrecoverable. ${ }^{49}$ Member States cannot limit this right by setting up burdensome formal requirements (e.g., requiring the timely lodging of the claim in an insolvency proceeding even if the claim is evidently not recoverable $;{ }^{50}$ requiring the debtor to still be registered as a taxable person ${ }^{51}$ ).

Both lines of case law are of increasing importance for VAT practice in today's special times and the upcoming months and years since the COVID pandemic will undoubtedly produce a significant number of distressed businesses and consumers who will be unable to fulfill their obligations on time.

\section{Revival: Double (nON-)taxation}

In theory, VAT (juridical) double (non-)taxation (i.e., taxation of the same supply in more than one Member State $)^{52}$ should not occur within the European Union since the place of supply rules are comprehensively harmonized by the EU VAT Directive without any possibilities for the Member States to deviate. ${ }^{53}$ Nevertheless, already in its early days, the CJEU was confronted with questions related to cases of potential VAT double (non-) taxation $^{54}$ caused by a different interpretation of the rules or a different assessments of the facts. ${ }^{55}$ In Cookies World in 2003, the CJEU emphasized that ' $[\mathrm{t}$ ] tax a supply of services in another Member State when it has already lawfully been subject to VAT in the State of the supplier of the services gives rise to double taxation contrary to the principle of fiscal neutrality inherent in the common system of VAT'. 56 The recent KrakVet judgment seems to contradict with this approach. Therein, the Court

\section{Notes}

39 CJEU 11 June 2020, Vodafone, Case C-43/19, ECLI:EU:C:2020:465.

40 CJEU 22 Nov. 2018, MEO, Case C-295/17, ECLI:EU:C:2018:942.

41 CJEU 23 Dec. 2015, Air France KLM, Joined Cases C-250/14 and C-289/14, ECLI:EU:C:2015:841.

42 MEO (C-295/17), supra n. 40, paras 61-62; Vodafone (C-43/19), supra n. 39, paras 40, 48.

43 Vodafone (C-43/19), supra n. 39, para. 40.

44 MEO (C-295/17), supra n. 40, para. 42.

45 Vodafone (C-43/19), supra n. 39, para. 34.

46 Ibid., para. 35; see also Air France KLM (C-250/14 and C-289/14), supra n. 41, para 28.

47 CJEU 18 July 2007, Société thermale d'Eugénie-Les-Bains, Case C-277/05, ECLI:EU:C:2007:440; see on this question G. von Streit \& T. Streit, Entgelt oder Schadensersatz? Oder: Die Mehrwertsteuer auf dem Weg zur Verkehrssteuer?, 69(14) UmsatzsteuerRundschau 525, 527 et seq. (2020).

48 CJEU 23 Nov. 2017, Di Maura, Case C-246/16, ECLI:EU:C:2017:887.

49 See also CJEU 29 Apr. 2020, Ramada Storax, Case C-756/19, ECLI:EU:C:2020:311.

50 CJEU 2 July 2009, SCT, Case C-111/08, ECLI:EU:C:2009:419.

51 CJEU 15 Oct. 2020, E, Case C-335/19, ECLI:EU:C:2020:829.

52 On the concept of (juridical) double taxation in VAT law: R. Ismer \& K. Artinger, International Double Taxation Under VAT: Causes and Possible Solutions, 45 (10) Intertax 593 (2017).

53 The only optional rule in Art. 59a VAT Directive is limited to scenarios involving non-EU Member States.

54 Berkholz (C-168/84), supra n. 7, para. 14; CJEU 12 May 2005, RAL, Case C-452/03, ECLI:EU:C:2005:289, para. 23.

55 On the causes of VAT double taxation see K. Spies, The CJEU's Approach in Direct Tax and VAT Law: Consistencies and Divergences, in CJEU - Recent Developments in Value Added Tax 2015 I, 135 (M. Lang et al. eds, Linde 2016).

56 CJEU 11 Sept. 2003, Cookies World, Case C-155/01, ECLI:EU:C:2003:449, para. 60. 
concluded - for a scenario in which Hungary and Poland presumably applied a different interpretation of the distance selling rules leading to potential double taxation - that neither the VAT Directive nor Regulation (EU) No 904/2010 prevents the tax authorities of a Member State from being able, unilaterally, to subject transactions to value added tax treatment different from that under which they have already been taxed in another Member State. 57 Stated differently, at the current stage, EU VAT law does not provide any obligation for Member States' authorities to avoid double taxation via administrative cooperation.

The KrakVet case demonstrates that, despite the 'full' harmonization of place of supply rules, VAT double taxation still exists in the EU. ${ }^{58}$ In light of the existing legal VAT framework, the CJEU's result is comprehensible; however, it appears to contradict the broader objectives of an internal market. Legal action is required. The problem had apparently already been known to the European Commission prior to KrakVet. In 2007, it launched a public consultation on VAT dispute issues; ${ }^{59}$ this work was continued in 2018 by establishing a subgroup to discuss potential dispute resolution and prevention mechanisms. ${ }^{60}$ An impact assessment possibly leading to a legislative initiative is to be expected in $2022 .{ }^{61}$

\section{New areas of interest}

\section{I Undisclosed Agents According to Article 28 VAT Directive}

The rule for undisclosed agents in Article 28 VAT Directive - although of immediate relevance for practice - was only minimally discussed at the Court level until 2019. ${ }^{62}$ This dramatically changed from 2019 to 2021; in this period, the CJEU ruled in four judgments on the interpretation of this rule. ${ }^{63}$ According to Article 28 VAT Directive, a taxable person who takes part in a supply of services and acts in his own name but on behalf of another person shall be deemed to have received and supplied those services himself. Article 28 - similar to the new Article 14a for online platforms applicable as of 1 July 2021 - thus creates the legal fiction of a chain transaction for VAT purposes that does not exist based on the civil law arrangements.

In all four referrals, the Court was asked whether Article 28 could apply to a specific case. It used this opportunity to develop on the general criteria of an undisclosed agent. In Amărăşti Land Investment SRL, the CJEU held that Article 28 is not subject to a consideration, i.e., it also applies if the agent does not receive a remuneration for the intermediation service. ${ }^{64}$ In ITH (not published in English!), the Court elaborated on the positive conditions of Article 28 and summarized them as follows: (1) the intermediary must act based on a contract with the person he represents, and (2) the intermediary should not modify/ alter the service or good (identity of the mediated supply). ${ }^{65}$ Considering the Amărăşti Land Investment SRL and $U C M R$ cases, a legal obligation or legal right for the agent to act may substitute the (necessary) contract between the represented person and the agent. ${ }^{66}$ For example, Article 28 may also apply to the activity of a collective copyright management organization if the holders of copyrights to music (represented persons) have not granted the organization (the agent) a specific authorization or mandate to collect the fees as long as the organization's activity is provided by the law. ${ }^{67}$

The undisclosed agent rule in Article 28 has already received (see Article 9a Implementing Regulation) and will continue to receive attention in the e-commerce sector. Due to the lack of a more precise definition, it is often ambiguous whether an electronic interface (online platform or Apps, e.g., Uber or Airbnb) acts as an undisclosed agent within Article 28, as a disclosed agent (intermediary) within Article 46, or on its own account. ${ }^{68}$ The result of this classification, however, is highly

\section{Notes}

57 CJEU 18 June 2020, KrakVet, Case C-276/18, ECLI:EU:C:2020:485, para. 97

58 E. Traversa, KrakVet Marek Batko (Case C-276/18): Against All Odds, VAT Double Taxation Exists in the EU, Kluwer International Tax Blog (27 July 2020), http:// kluwertaxblog.com/2020/07/27/krakvet-marek-batko-case-c-276-18-against-all-odds-vat-double-taxation-exists-in-the-eu/ (accessed 10 Feb. 2021).

59 European Commission, VAT - Possible Introduction of a Mechanism for Eliminating Double Taxation in Individual Cases (31 May 2007), https://ec.europa.eu/taxation_customs/ consultations-get-involved/tax-consultations/vat-possible-introduction-a-mechanism-eliminating-double-taxation-individual-cases_en (accessed 3 Mar. 2021).

60 EU VAT Forum, Report: Prevention and Solution of VAT Double Taxation Dispute (23 Jan. 2020), III-20-(VAT Forum)-2.

61 See European Commission, Communication from the Commission to the European Parliament and the Council, An Action Plan for a Fair and Simple Taxation, Annex A16, $\operatorname{COM}(2020) 312$ (15 July 2020).

62 It was only addressed briefly in the CJEU 14 July 2011, Henfling u. a., Case C-464/10, ECLI:EU:C:2011:489; CJEU 4 May 2017, European Commission v. Luxembourg, Case C274/15, ECLI:EU:C:2017:333.

63 CJEU 19 Dec. 2019, Amărăşti Land Investment SRL, Case C-707/18, ECLI:EU:C:2019:1136; CJEU 16 Sept. 2020, XT, Case C-312/19, ECLI:EU:C:2020:711; CJEU 12 Nov. 2020, ITH, Case C-734/19, ECLI:EU:C:2020:919; CJEU 21 Jan. 2021, UCMR, Case C-501/19, ECLI:EU:C:2021:50.

64 Amărăşti Land Investment SRL (C-707/18), supra n. 63, para. 42

65 ITH (C-734/19), supra n. 63, para. 51

66 Amărăşti Land Investment SRL (C-707/18), supra n. 63, para. 40; UCMR (C-501/19), supra n. 63, para. 47.

$67 \operatorname{UCMR}(\mathrm{C}-501 / 19)$, supra n. 63, para. 47.

68 See on this issue, inter alia, European Commission, VEG No. 095, 5 Oct. 2020, taxud.c.1(2020)5816454 (29 Sept. 2020). 
relevant as it decides on the qualification of the supply chain for VAT purposes, the applicable place of supply rule, the tax rate, exemptions, and the relevant collection mechanism (MOSS). A mismatch of this classification between Member States' authorities can lead to double taxation or non-taxation of the underlying services. ${ }^{69}$

\subsection{Refund of Input VAT}

Another new area of interest at the Court's level are the conditions for refund of input VAT based on the Refund Directives (Directive 2008/9/EC and Thirteenth Directive 86/560/EEC). Overall, the CJEU demonstrates a tendency to limit administrative practice in different Member States by either relying on the neutrality principle alone ${ }^{70}$ or in conjunction with the principle of proportionality. ${ }^{71}$ This development already began in 2018/2019 with the Volkswagen $A G^{72}$ and Sea Chefs Cruise Services cases ${ }^{73}$ and was continued by three more judgments in 2020 (surprisingly, two are not published in English!). ${ }^{74}$ In all three cases in 2020, the Court ruled in favour of businesses and found that the respective Member States (Germany, Romania) had violated EU law by making the request for refund of input VAT by non-resident taxable persons subject to disproportional conditions.

In CHEP, the Court held that Romania cannot deny the right to the refund of VAT solely on the (formal) grounds that the taxable person is registered for VAT purposes in the Member State of the refund. The decisive substantive conditions for a VAT refund are that the taxable person (1) is not established in the Member State of the refund and (2) does not provide taxable supplies in the Member State of the refund. The fact that a taxable person may be registered for VAT purposes in the Member State of the refund cannot be regarded as evidence that that taxable person has actually carried out taxable transactions in that Member State. ${ }^{75}$ In the other two cases involving Germany, the Court ruled that the administrative practice of systematically rejecting incomplete refund applications (due to non-attachment of incoming invoices or missing sequential invoice numbers) is not in accordance with EU law. The applicant must first be asked to supplement the application accordingly; the VAT refund can only be denied if the taxpayer fails to fulfill this request. ${ }^{76}$ These judgments might also have an effect on other Member States' administrative practice.

\section{Old AND New Key CONCEPTS OF VAT LAW}

Besides topical areas of interest, these recent examples in CJEU case law demonstrate the Court's effort to develop and rely on general principles when dealing with specific interpretation questions. Thereby, the CJEU appears to be keen to build a consistent 'house of VAT' with foundations (= general principles) to make the VAT system and its interpretation more robust and the outcome of specific cases more predictable. Whereas some principles are well-known, new relevant principles have also gained increasing relevance in the last years. In light of 2020 case law, part of these 'foundations of the VAT house' are, in particular, the principle of neutrality, the principle of proportionality, and the principle of 'economic reality'. Others might be the anti-abuse doctrine (also labelled as 'general principle that abusive practices are prohibited ${ }^{77}$ ) and the principle of strict interpretation of exceptions. ${ }^{78}$

\section{I The Principle of Neutrality}

The principle of neutrality is the 'fundamental principle of the common system of $\mathrm{VAT}^{, 79}$ and has been used by the CJEU since the first VAT cases. ${ }^{80}$ Only beginning in the 2000s, the CJEU has sharpened its scope and effects ${ }^{81}$ and also attempted to distinguish it from the EU general

\section{Notes}

69 See P. Rendahl, EU VAT and Double Taxation: A Fine Line Between Interpretation and Application, 41(8/9) Intertax 450, 450 (2013).

70 CJEU 11 June 2020, CHEP, Case C-242/19, ECLI:EU:C:2020:466; CJEU 18 Nov. 2020, European Commission v. Germany, Case C-371/19, ECLI:EU:C:2020:936; CJEU 2 May 2019, Sea Chefs Cruise Services, Case C-133/18, ECLI:EU:C:2019:354; CJEU 21 Mar. 2018, Volkswagen AG, Case C-533/16, ECLI:EU:C:2018:204.

1 CJEU 17 Dec. 2020, Bundeszentralamt für Steuern, Case C-346/19, ECLI:EU:C:2020:1050.

Volkswagen AG (C-533/16), supra n. 70 .

Sea Chefs Cruise Services (C-133/18), supra n. 70.

74 CHEP (C-242/19), supra n. 70 (not published in English); European Commission v. Germany (C-371/19), supra n. 70 (not published in English); Bundeszentralamt für Steuern (C346/19), supra n. 71.

75 CHEP (C-242/19), supra n. 70, paras 55 et seq.

76 European Commission v. Germany (C-371/19), supra n. 70; Bundeszentralamt für Steuern (C-346/19), supra n. 71

77 CJEU 22 Nov. 2017, Cussens, Case C-251/16, ECLI:EU:C:2017:881, para. 38.

78 See on principles in EU VAT law, also R. de la Feria, EU VAT Principles as Interpretative Aids to EU VAT Rules: The Inberent Paradox, in CJEU - Recent Developments in Value Added Tax 2015 I, 3 (M. Lang et al. eds, Linde 2016).

79 CJEU 19 Sept. 2000, Schmeink \& Cofreth, Case C-454/98, ECLI:EU:C:2000:469, para. 59.

80 CJEU 14 Feb. 1985, Rompelman, Case C-268/83, ECLI:EU:C:1985:74, paras 19 and 23.

81 CJEU 10 Apr. 2008, Marks \& Spencer, Case C-309/06, ECLI:EU:C:2008:211, paras 46-54; CJEU 29 Oct. 2009, NCC, Case C-174/08, ECLI:EU:C:2009:669, paras 39-44; CJEU 19 July 2012, Deutsche Bank, Case C-44/11, ECLI:EU:C:2012:484, para. 45; CJEU 15 Nov. 2012, Zimmermann, Case C-174/11, ECLI:EU:C:2012:716, paras 46-50. 
principle of equal treatment ${ }^{82}$ (a distinction not quite easy to understand). As illustrated in the 2020 case law, it is particularly used by the Court as a key argument when interpreting the provisions on the right to input VAT deduction/refund and the taxable amount. Although the Court sometimes emphasizes that this principle cannot be used to extend the scope of a rule beyond the wording of a specific provision (in particular in the field of exemptions $)^{83}$, it has also used this principle to derive at results that are not easily reconciled with the letters of the law (in particular in the field of input VAT credit). ${ }^{84}$

\subsection{The Principle of Proportionality}

According to the CJEU, the principle of proportionality is 'one of the general principles of EU law'. ${ }^{85}$ It is thus - differently than the neutrality principle and the concept of 'economic reality' - not a VAT specific concept. This principle is similar to an 'abstract objectivity and rationality test' that is applicable to any EU rule including VAT law. ${ }^{86}$ The CJEU makes use of this concept in VAT law whenever measures taken by Member States' legislators or authorities seem to be very burdensome and potentially involve excessive compliance costs or risks for businesses. It thus helps the Court to retain costs at a certain minimum level for the taxable persons who act as an unpaid 'tax collector on behalf of the state ${ }^{, 87}$. From a dogmatic perspective, this principle - as applied by the Court to VAT cases - has a very close link to the fundamental rights enshrined in the EU Charter of Fundamental Rights (in particular the freedom to conduct business). ${ }^{88}$ It might be questioned whether it would be more advantageous for the Court to rely on these fundamental rights as a legal basis rather than the vague concept of "proportionality' as a separate principle.

\subsection{The Principle of Economic Reality}

The vague concept of 'economic reality' has played an increasing role in the Court's case law in recent years. ${ }^{89}$ According to the Court, the concept of 'economic reality' constitutes a 'fundamental criterion for the application of the common system of VAT' ${ }^{90}$ This concept seems to be a VAT specific 'substance-over-form' approach and has been applied by the Court in different areas to requalify civil law contracts and qualifications for VAT purposes, among others, regarding supply chains, ${ }^{91}$ payments, ${ }^{92}$ legal capacities of persons, ${ }^{93}$ and the nature of a service. ${ }^{94}$ The concept of 'economic reality' goes beyond the antiabuse doctrine as developed in Halifax since it does not involve a similar two-prong test (subjective and objective conditions). ${ }^{95}$ As a transaction tax aiming at taxing consumption (expenditure), VAT builds on persons and transactions that are recognized in the market. If VAT is - based on this principle - no longer to adhere to contractual terms and arrangements, what should it follow? As this seemingly new concept is not sharply defined, it places legal certainty - which is also a general principle of EU law ${ }^{96}$ - at risk. ${ }^{97}$

\section{THE NEED FOR PRINCIPLES}

While the reliance on 'principles' in the interpretation process might initially seem to be 'good' as it could potentially allow establishing a (more) coherent overall approach, upon closer examination, this is not necessarily true. 'Principles' are inherently vague legal concepts that lack clear definitions regarding their scope and effects; they sometimes also potentially overlap and/or contradict each other. This is also illustrated by the CJEU case law on the neutrality principle for which the Court itself had

\section{Notes}

82 Marks E Spencer (C-309/06), supra n. 81, para. 49; Zimmermann (C-174/11), supra n. 81, para. 50.

83 Deutsche Bank (C-44/11), supra n. 81, para. 45.

84 CJEU 6 Dec. 2005, Gaston Schul, Case C-461/03, ECLI:EU:C:2005:742 (input VAT deduction despite not being explicitly provided for in the directive); CJEU 15 Sept. 2016, Barlis, Case C-516/14, ECLI:EU:C:2016:690 (correct invoice not required for input VAT deduction although mentioned in the directive)

85 Di Maura (C-246/16), supra n. 48, para. 25.

86 Spies, supra n. 12, at 75.

87 Di Maura (C-246/16), supra n. 48, para. 23.

88 See Di Maura (C-246/16), supra n. 48, paras 25 et seq.; and opinion by AG Kokott, 8 June 2017, Di Maura, C-246/16, ECLI:EU:C:2017:440, points 45 et seq.; Spies, supra. 12 , at 76 .

89 See also the recent discussions by van Doesum \& Nellen, supra n. 38, at 213.

90 CJEU 20 June 2013, Newey, Case C-653/11, ECLI:EU:C:2013:409, para. 42; Vodafone (C-43/19), supra n. 39

91 Newey (C-653/11), supra n. 90.

92 MEO (C-295/17), supra n. 40; Vodafone (C-43/19), supra n. 39.

93 Dong Yang (C-547/18), supra n. 3; implicitly similar DFDS (C-260/95), supra n. 9.

94 CJEU 26 May 2016, Bookit, Case C-607/14, ECLI:EU:C:2016:355, para. 27 et seq.; CJEU 22 Feb. 2018, T-2, Case C-396/16, ECLI:EU:C:2018:109, paras 43-45.

95 See also the opinion by AG Kokott compared to the CJEU judgment in the Dong Yang case. In contrast to the Court, AG Kokott denied that the subsidiary can be an FE of the parent in the Dong Yang case since there was no risk of tax revenues losses and, hence, no abuse, in place (Opinion AG Kokott, 14 Nov. 2019, Case C-547/18, Dong Yang, ECLI:EU:C:2019:976, points 47 et seq.)

96 See CJEU 12 Feb. 2015, Parliament v. Council, Case C-48/14, ECLI:EU:C:2015:91, paras 45 et seq.

97 AG Kokott, Dong Yang (C-547/18), supra n. 95, point 65; Lasinski-Sulecki, supra n. 26, at 194; van Doesum \& Nellen, supra 38 , at 226. 
to acknowledge that the "concept of neutrality is used in different senses' 98 and 'requires legislation to be drafted and enacted' in order to be effective. ${ }^{99}$ These statements reveal that the neutrality principle - as any other principle - does not have an autonomous meaning independent of any provision. It can only have effect by taking into account the specific subject matter in question. In the author's opinion, therefore, the extensive use of principles as a basis for interpretation of a specific provision makes the reasoning in judgments not always more comprehensible but may - on the contrary - lead to open questions and hide the 'real' reasons for a specific result. Without referring to 'principles', judges would likely reach the same conclusions in many cases but would be obligated to explain their reasoning in more detail, relying on grammatical, historic, systematic, and teleological interpretation of the specific provision in question.

Karoline Spies*

Full professor and holds a chair in tax law at the Institute for Austrian and International Tax Law at Vienna University of Economics and Business (WU). Since 2019, she has been a member of the VAT Expert Group at the European Commission

E-mail:Karoline.Spies@wu.ac.at.

\section{Notes}

98 Zimmermann (C-174/11), supra n. 81, para. 46.

99 NCC (C-174/08), supra n. 81, para. 42.

* The author would like to thank Yasmin Lawson, LL.M., for her support with the literature research. 